María José Estarán, Francisco Beltrán, Eduardo Orduña and Joaquín Gorrochategui

\title{
3 Hesperia, a Database for Palaeohispanic Languages; and AELAW, a Database for the Ancient European Languages and Writings. Challenges, Solutions, Prospects
}

\begin{abstract}
Hesperia. Banco de datos de lenguas paleohispánicas and AELAW. Ancient European Languages and Writings are two narrowly linked projects whose common feature is their general aim: cataloguing the documents written in the ancient languages of Europe ( $8^{\text {th }}$ cent. BCE- $5^{\text {th }}$ cent. CE) excluding Latin, Greek, and Phoenician. Although both projects are closely linked, BDHesp has a track record of twenty years, while AELAW has been active for only two and a half years. In this paper, where we have especially focused on BDHesp, we summarize the problems that arose during the encoding of Palaeohispanic languages, written in multiple writing systems and their variants, and the solutions addressed. We also present the promising tools that have been developed in BDHesp to make significant progress in our understanding of Palaeohispanic languages and writings. Lastly, we introduce AELAW network and its two databases, its aims and what we intend to accomplish in the future.
\end{abstract}

Keywords: Palaeohispanic languages, Palaeohispanic writings, ancient languages of Europe, partially deciphered script, digital epigraphy

\footnotetext{
María José Estarán, University of Nottingham, LatinNow Project (ERC-2016-STG 715626)

Francisco Beltrán, Universidad de Zaragoza

Eduardo Orduña, IES Pont de Suert

Joaquín Gorrochategui, Universidad del País Vasco/Euskal Herriko Unibertsitatea, J. Gorrochategui is PI of the project "Hesperia: lenguas, epigrafía y onomástica paleohispánica”, funded by MINECO/ FEDER (FFI2015-63981-C3). The rest of the authors of this paper are active members of this project.
} 


\subsection{Introduction to BDHesp and AELAW Databases}

Hesperia. Banco de datos de lenguas paleohispánicas ${ }^{1}$ and AELAW. Ancient European Languages and Writings ${ }^{2}$ are two narrowly linked projects whose common feature is their general aim: cataloguing the documents written in the ancient languages of Europe ( $8^{\text {th }}$ cent. BCE- $5^{\text {th }}$ cent. CE) excluding Latin, Greek, and Phoenician.

The purpose of Hesperia. Banco de datos de lenguas paleohispánicas (henceforth BDHesp) is to collect the inscriptions written in any of the pre-Roman languages known in Hispania and Southeastern Gaul, including coin legends. Its distinctive feature is that it is not a mere compilation of epigraphs (i.e. a sylloge or an editio minor of the texts known so far); on the contrary, it meets the criteria of a genuine editio maior, where every text has been analysed accurately and every file is provided with a critical apparatus of the text, as well as with pictures or drawings (Luján, 2005; Orduña, Luján \& Estarán, 2009; Orduña \& Luján, 2014; Orduña \& Luján, forthcoming).

This project began in 1997 and it is currently being developed by four teams based in the Universitat de Barcelona (UB), Universidad Complutense de Madrid (UCM), Universidad de Zaragoza (UZ) and Universidad del País Vasco / Euskal Herriko Unibertsitatea (UPV/EHU), thanks to the funding of the Plan nacional de $I+D+i$, sponsored at present by the Spanish Ministerio de Economía y Competitividad. The project was initiated under the direction of Javier de Hoz (UCM) and it is presently coordinated by Joaquín Gorrochategui (UPV/EHU). J. Velaza (UB), E. Luján (UCM) and F. Beltrán (UZ) are the individuals responsible for the rest of the teams.

As for AELAW, it is focused on the creation of a network of researchers working on the European languages spoken and written in Antiquity, excepting Latin, Greek and Phoenician. Its final goal is to lay the foundations of a databank that could group every inscription written in one of these ancient European languages. Its mediumterm partial goals are 1) to create a census of languages; 2) to create a census of inscriptions; 3) to fix the criteria for the digital edition of inscriptions; 4) to define the technical features of the future Databank. The AELAW network was born in 2015 thanks to a European Cooperation in Science and Technology Action (COST IS1407). This action will last until 2019.

The network, whose chair is F. Beltrán (UZ), is currently composed of researchers working for 29 institutions based in 13 countries. AELAW emerged as an initiative of the Spanish researchers belonging to the Hesperia project with the purpose of providing the ancient European epigraphic ensembles with a tool, which could be similar to BDHesp. As a consequence, both projects are closely linked. However, we would like to underline that BDHesp has a track record of twenty years, while AELAW

1 [http://hesperia.ucm.es/].

2 [http://aelaw.unizar.es/]. 
has been active for just two and a half years, hence the presentation of each database in this paper is clearly unbalanced towards the first project.

\subsection{Palaeohispanic Languages and Writings}

The Iberian Peninsula is a region with a high linguistic heterogeneity where three colonial languages (Phoenician, Greek and Latin) and five vernacular languages belonging to different linguistic groups are recognised. More than two thousand inscriptions written in these local languages and writings, dating from the $7^{\text {th }}$ cent. BCE to $1^{\text {st }} / 2^{\text {nd }}$ cent. CE (when they were substituted by the Latin language and alphabet) have been discovered so far. The four languages epigraphically recorded are, in a diachronic order: the so-called Southwestern language (or “Tartessian language”), Iberian, Celtiberian and Lusitanian. To these should be added the Vasconic language, known by onomastics and possibly by certain short texts, although it is still a controversial question.

The Iberian language is also recognised in Southeastern France (west of the Hérault river). Aquitanian, a language that was closely related to Vasconic, and is known only through some personal and god names, was spoken on the other side of Pyrenees. The Vasconic-Aquitanian remains are clearly linked to the currently spoken Basque language, albeit Ancient Vasconic is better attested in Navarre and the northern territory of Zaragoza (Aragon) than in the area corresponding today to the Basque Country, where the epigraphic records are mainly related to the Celtic languages.

The Celtiberian language belongs to the Celtic branch, such as Gaulish and Lepontic in Antiquity, or other currently spoken languages such as Brittonic, Gallic or Irish. The Lusitanian language is clearly an Indo-European language, although there is not yet consensus on its belonging to the Celtic branch, since Lusitanian presents some characteristics that differ from the Celtic features: the Lusitanian inscriptions retain Indo-European *p-. The classification of the so-called "Southwestern language" poses even more problems, since its writing system is only partially deciphered. Some researchers consider that it is also a Celtic language, although it is a minority opinion. As for the Iberian language, researchers have been able to determine that it seems an agglutinative language. It remains unclassified, without known parallels, although it presents some similarities with the Vasconic group that are still insufficient to confirm a direct connection between both languages.

The texts that were written in these languages mainly used a writing system called "Palaeohispanic", which originated in the Iberian Peninsula, whose most distinctive feature is the use of both alphabetic graphemes (for vowels, sonants and sibilants) and syllabic graphemes (unvoiced and voiced plosives). At least four variants (possibly five) of this "semi-syllabic" writing system have been identified: 1) The variant used for the inscriptions written in the "Southwestern" language; 2) and 3) The variants 
of the Iberian-speaking region, along the Mediterranean coast and its inland, between Southern France and Almeria; 4) The Celtiberian variant, spread along the Sistema Iberico (an inner mountain chain); 5) and maybe a "Vasconic" variant in the Northwestern Middle Ebro Valley, where these Vasconic speaking peoples and other related peoples were settled. Besides, the Iberian language was written in a variant of the Greek Ionic alphabet and, exceptionally, in the Latin alphabet. The Latin alphabet was often used, in turn, for transcribing the Celtiberian language (with some minor modifications) in an advanced stage of Romanization. The Latin alphabet is also the writing system of the scarce Lusitanian texts, without exceptions.

These four linguistic groups cover the Southern half of Hispania and its Far East. On the contrary, the West remained illiterate until the Roman conquest (late $1^{\text {st }}$ cent. $\mathrm{BCE})$, where no vernacular language is occurring in any inscription, since their texts were written in the Latin language from the beginning.

The Southwestern language is evidenced between the $7^{\text {th }}$ and $4^{\text {th }}$ centuries BCE on instrumenta, but above all on stone: funerary texts with a striking helicoidal layout were inscribed on circa two hundred stones. The variant of the Palaeohispanic writing system used there has not been completely deciphered up to date and, as a consequence, the linguistic classification of this poorly known language is under discussion.

The Iberian language is the best evidenced of all the Palaeohispanic languages. More than two thousand inscriptions written in this language are dated between the $5^{\text {th }}$ century and the $1^{\text {st }}$ century BCE (some epigraphs could even be dated in the $1^{\text {st }}-2^{\text {nd }}$ centuries CE). The oldest inscriptions are written in a variant of the Greek alphabet (in a restricted region near Alicante) or in a variant of the Palaeohispanic writing system. Short texts on instrumentum, and longer texts related to trade or economic activities on lead tablets are the documents one can find in the earliest stages of the Iberian epigraphy. In tandem with the Roman conquest, literacy spread inland from the $2^{\text {nd }}$ century BCE onwards. From that moment on, we move to an intensification and diversification of the epigraphic habit: monumental inscriptions, aimed to be publicly displayed and contemplated, and funerary steles and slabs are the most remarkable novelties; but important changes in coin legends and mosaic inscriptions occurred as well. The lack of linguistic parallels for the Iberian language makes this language very difficult to understand. Only personal names have been identified, and the sense of some words has been perceived in only a tentative way.

Simultaneously, from the $2^{\text {nd }}$ century BCE on, literacy spread to the Celtiberian area, where some hundreds of inscriptions have been collected, mostly on instrumentum, albeit scarcely more than a dozen on monuments on stone have been found, as well as twenty instances of graffiti inscribed on a rock sanctuary, approximately forty tesserae hospitales on little bronze objects and around ten inscriptions, some of them extraordinarily long, on bronze plaques and tablets. Although the Celtiberian language cannot yet be translated, the linguistic comparison with other Celtic and 
Indo-European languages allows an understanding of its morphology and syntax and, therefore, of some words and word sequences.

Lastly, the Lusitanian language is only evidenced in half a dozen stone and rock inscriptions of a religious nature, where some theonyms and references to animal sacrifices have been identified. All Lusitanian texts are written in the Latin alphabet. Apart from this small ensemble of inscriptions, a group of altars inscribed with the Latin language from the Lusitanian region, bear religious dedications to local gods whose theonyms show Lusitanian morphological traces.

The reference work for Palaeohispanic inscriptions are the four volumes of Monumenta Linguarum Hispanicarum, published by Jürgen Untermann since 1975, that BDHesp intends to update.

\subsection{BDHesp (Banco de Datos de Lenguas Paleohispánicas Hesperia)}

Hesperia, the Databank for Palaeohispanic Languages (Figure 3.1) is based on Untermann's $M L H$ and Wodtko 2000 and, following the lines of this corpus, the epigraphic material is organized territorially. This is structured according to the current Spanish and Portuguese provinces and the French départements.

The implementation of this project has been possible thanks to Eduardo Orduña. He has built the Databank on LAMP, the software bundle consisting of the software operating system Linux, the web server Apache, the relational database management system MySQL and the programming language PHP, all them leading representatives of the free software and of the open source code, as well as MapServer, developed by the University of Minnesota, which has been used for the generation of the maps.

The aim of Hesperia is, with the help of computational resources to create a linguistic and epigraphic database that allows us to develop our precarious knowledge of Palaeohispanic languages and writings. This databank facilitates compilation of all the published Palaeohispanic inscriptions with a complete set of information (the identification of each inscription and its text; epigraphic, linguistic and archaeological commentaries; bibliographic references and pictures), as well as adding new files and improving those previously published. The fact it is not a simple data collection, but a critically edited file, is what gives BDHesp a relevant scientific value. 


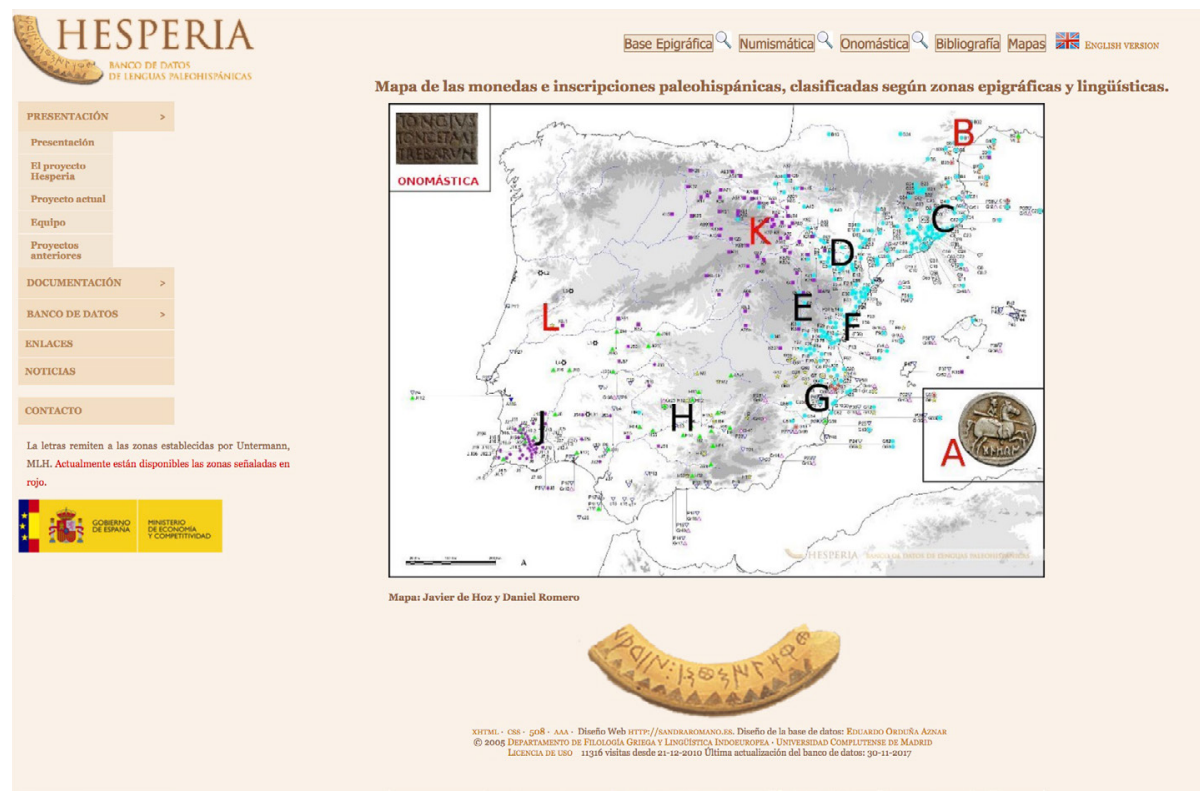

Figure 3.1: Home page of Hesperia

\subsubsection{Developing BDHesp: From an Epigraphic Database to a Databank of Palaeohispanic Languages}

The BDHesp coordinators decided to create two more databases besides the epigraphic one: a database for coin legends and another one for bibliographic references. The numismatic database (Estarán \& Beltrán, 2015) was clearly inspired by Untermann's $M L H$, where epigraphy on coins is collected in an independent volume. The information included in this database doesn't cross automatically with the epigraphic database, while the files in the bibliographic database do. This second database contains all the bibliographic references mentioned both in the epigraphic and in the numismatic database. As a consequence, the original epigraphic database becomes a databank. As BDHesp progressed, more tools were created and linked to the numismatic and epigraphic databases: a map generator and a search engine. These were improved, as new needs arose in the creation of files. At present, the BDHesp team continues to develop new tools and databases. Indeed, a brand new database has been recently opened within this databank to collect onomastics (Vallejo, 2016), since personal names and theonyms play a fundamental role for research on the ancient languages of certain areas where texts written in the vernacular languages are absent (Gorrochategui \& Vallejo, forthcoming). Work-in-progress is being carried 
out in another database devoted to the lexicon, which will be accessible in the very near future.

Likewise, the database of the ENCEOM project (ENCEOM, El nacimiento de las culturas epigráficas del Occidente Mediterráneo, Ministerio de Economía y Competitividad, PI: F. Beltrán Lloris) has been recently prepared to be incorporated into BDHesp. Although this project is not directly related to Hesperia, its files were designed to be compatible with BDHesp from the very beginning. This database currently includes more than 750 files of publicly displayed inscriptions of the most relevant epigraphic cultures of the Roman West (Iberian, Celtiberian, Lusitanian, Gaulish, Oscan, Umbrian, Phoenician / Punic and some Etruscan inscriptions as well).

The multidisciplinarity of the team of project Hesperia has been essential for developing very complete files, containing comments on the epigraphic material, the archaeological context, the linguistic exploitation of the texts, etc. All this information can be easily found thanks to the search engine.

\subsubsection{Challenges Arising from the Digitalization of Palaeohispanic Epigraphy and Solutions Adressed in BDHesp}

The digitalization of Palaeohispanic epigraphy has posed some challenges related to codification and computational lexicography.

- Codification. The main problems regarding codification that have been faced are, on the one hand, processing texts written in different writing systems and, on the other hand, the existence of certain Palaeohispanic graphemes, on whose phonetic content there is not yet consensus among the researchers. The first one has been relatively solved thanks to the transcription of the Palaeohispanic texts in the Latin alphabet within the files. ${ }^{3}$ E. Orduña created buttons with diacritic symbols, or for introducing bold and italic letters, in order to facilitate the introduction of Palaeohispanic texts without having to deal with codes, which might have caused several problems if done incorrectly. Regarding the second problem, E. Orduña proposed the option "Personalizar transcripción" ("Customize transcription"), which gives the user the possibility of choosing the phonetic value assigned to every doubtful grapheme. A specific search engine based on this system has been implemented for the texts of the inscriptions written both in the Southern Iberian script (a variant of the Palaeohispanic Iberian script) and in the Southwestern writing system, which are only partially

3 If the potential user is interested in knowing more about Palaeohispanic writing systems, he or she can visit [http://hesperia.ucm.es/escrituras.php], where some explanations and tables with graphemes and alographs have been uploaded. 
deciphered. Its strength lies in the possibility of assigning different values to every sign, permitting the different reading options to be seen immediately. Additionally, the user can see the undeciphered graphemes as images. However, the best-known variants of the Palaeohispanic writing system (Northwestern Iberian and Celtiberian variants) present specific problems of codification, namely the existence of different transcription systems in the current research. This problem affects mainly inscriptions distinguishing the marked and unmarked syllabograms that might correspond to a distinction of voiced and voiceless plosives respectively. Some researchers transcribe them as such (e.g. ta/da, ka/ga); some others prefer a more restricted system that only reflects the marked or unmarked nature of the Palaeohispanic grapheme (tá/ta, ká/ka). Through the internal use of regular expressions, it has been possible to develop a system that allows the user to choose the transcription system that best suits his or her needs. Lastly, a problem concerning every transcription system is the use of underdots, or underlining, to mark a doubtful or incomplete reading, which means an added difficulty for the search engine. This problem has been solved using Unicode diacritics to transcribe these signs, in order to benefit from the power of the system of regular expressions of the PHP language, which permits them to be ignored in the searches.

- Access to information. BDHesp has been designed with the aim of facilitating the access to the huge amount of data contained in it, which has been solved in diverse ways: 1) the user can get access to the files not only from the search engine, but also from the map server. The maps contain clickable marked places that connect automatically to the corresponding epigraphic file; 2) once the user has filtered the information with his or her desired criteria through the search engine, the user can choose the layout of the results (like a list or like the pages of a book), in order to provide comfortable reading; 3 ) if the user is looking for certain regular expression, which is especially useful for determining patterns in Palaeohispanic texts, he or she can introduce the desired expression in the search engine. It will provide a complete list that may include eventual variants. These possibilities make the BDHesp search engine an indispensable tool to make significant progress in the deciphering of Palaeohispanic texts, since it offers an easy access to data that otherwise would be very tiresome to obtain: the reading variants of the search results appear as bubbles on the selected reading when the cursor is hovered over them; in the same way, bibliographical references appear on the abbreviated ones. Lastly, BDHesp developers have not only considered the screen layout, but also the printed layout: it is possible to generate PDF files with all the information, or the data the user has previously selected, of one file or a group of them, including pictures and drawings of the inscriptions.

- Computational lexicography. Each database in BDHesp has different aims, so BDHesp developers reflected deeply on the special needs of each one before achieving the final design, and therefore on the units in which these databases 
were going to be structured. The dominant criterion for structuring each unit was, in all cases, the ease of reference online.

For example, the unit is the mint (the city that issued the coins) in the numismatic database, thus files for coin legends are grouped in their respective mint files. If the unit were every different legend, the searches would have been less straightforward for the user (nonetheless, this database has two combined search engines: one for mints and another for coin legends, in case the user should be interested in a particular coin legend). On the contrary, the lexicographic unit of the epigraphic database is not the archaeological site or the ancient city where the inscriptions were found, but the inscription itself. Of course, inscriptions are geographically grouped; but there is not a specific file for each site or place. On the other hand, the unit of the onomastic database is obviously different from the other two databases: each personal name, theonym or toponym is the unit of a file. This selection was fundamental both to know their frequency and the cartographic distribution. Similarly, in the lexicon database, each lexical element must be isolated so as to be individually studied.

In this sense, an additional problem has emerged when linking the epigraphic database with the lexicon database: the identification of "words". In essence, it is already solved, although it is not yet publicly accessible. For instance, we cannot yet identify "words" in Iberian with certainty, given our precarious knowledge of this language. That is why each entry of the BDHesp lexicon corresponds with the segments that were separated with interpuncts by the Iberians themselves. The programme uses these signs to internally convert the text of the inscription in an array with each segment, and, after that, it executes a loop comparing each element of the array with the entries of the lexicon. Then it generates a new version of the text on the screen, where every word appears like a link to its corresponding entry of the lexicon. The use of regular expressions in the comparison even allows the creation of links to non-exact corresponding entries, ignoring lost signs or problems of transcription, for example.

- Small-scale geographic view. We have already mentioned the possibility of dynamically generating location maps of inscriptions. The existing possibility of loading layers of external servers, like Google Maps (with satellite view) or local layers (like georeferenced maps), allows us to foresee future challenges: a collaboration with archaeologists could provide precise geographic coordinates for the location of findings in a site, so that we could visualize the distribution of the inscriptions on the satellite photograph or on the georeferenced plan of the site.

- Interoperability. BDHesp has not yet taken the leap to the compatibility with other epigraphic databases, probably because no other database is thematically related (only with the future database AELAW, see below); and a need of associating with a thematically unrelated database has not arisen, since, for example, the mapping software is already incorporated in BDHesp. 
In sum, BDHesp could be considered as the indispensable tool for researchers in Palaeohispanic languages and cultures. Thanks to its computational resources (search engine, mapping software, the possibility for the user of reading simultaneously the official reading and its variants, or of choosing the phonetic values for the doubtful graphemes, etc.), the research is going to progress profoundly in our knowledge of the Palaeohispanic languages and writings.

\subsection{AELAW}

The concept of AELAW is clearly different from that of Hesperia. The COST Action Ancient European Languages and Writings began in 2015 and, as has been underlined before, it is inspired by BDHesp to a large extent. The main aim of this action, funded by the European Union through the programme European Cooperation in Science and Technology (COST), is to create a network of researchers working on ancient European languages and writings through the establishment of links between universities and research centres. This network will overcome the existing fragmentation among the researchers of the different Palaeo-European epigraphic cultures.

This network must generate links that ease the cooperation, the exchange of experiences and the sharing of advances made in the research on each corpus language in order to find solutions to the various problems each region poses. The training of early-stage researchers through short-term scientific missions, training schools, workshops and conferences, is considered particularly relevant. Additionally, we intend to establish the criteria for critical editions online and to develop a databank that will contain all the Palaeo-European inscriptions.

The AELAW network promotes multiple scientific activities and meetings and publications, among which the collection of AELAW Booklets stands out. These booklets provide accurate and attractive introductions to the epigraphic production of each fragmentary, but evidenced language (Beltrán \& Jordán, 2017a, 2017b; Salomon, 2017a, 2017b; Velaza \& Moncunill, 2017a, 2017b; Wodtko, 2017a, 2017b). 


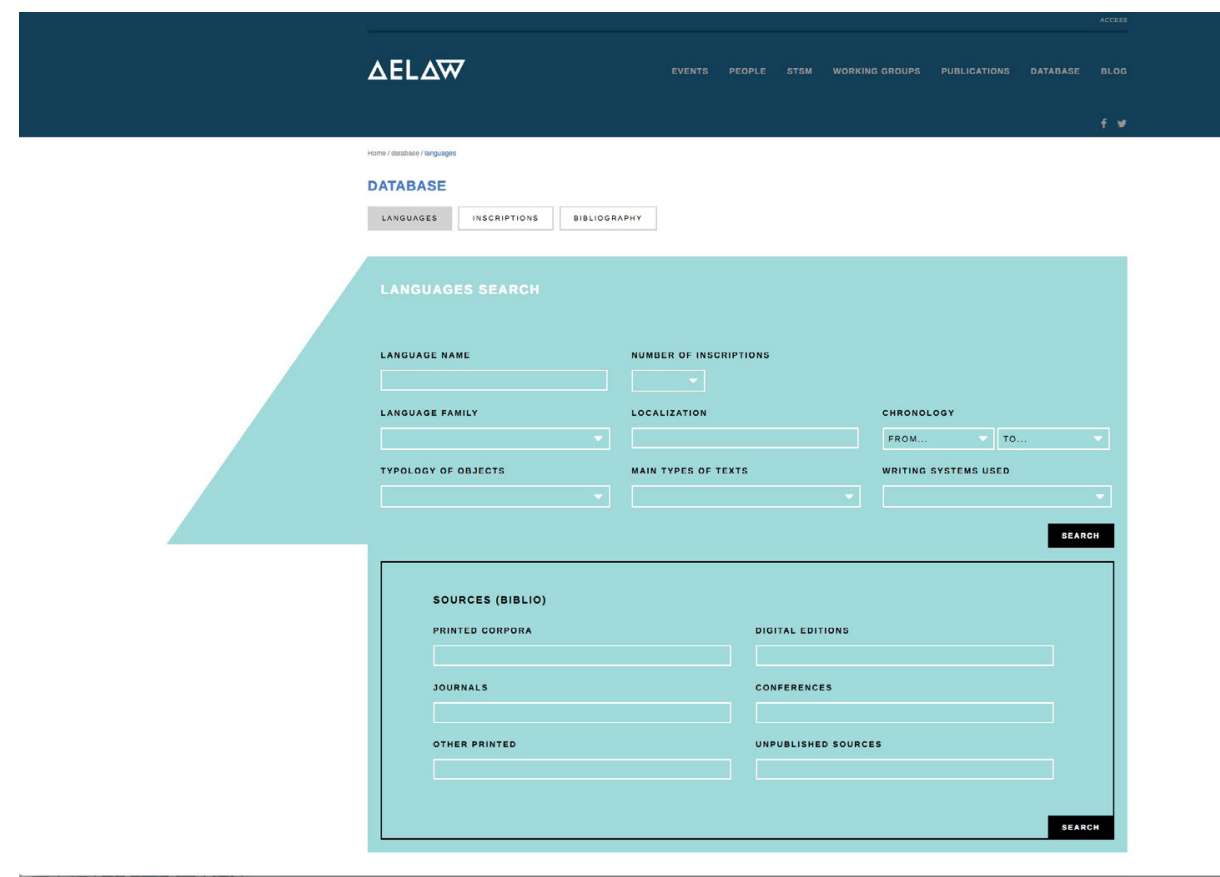

Figure 3.2: Home page of the AELAW Database ${ }^{4}$

\subsubsection{Developing of the AELAW Database}

In line with the main aim of this network, which is designing the future database of all the Palaeo-European fragmentary attested languages (excepting Latin, Greek and Phoenician; Figure 3.2), it is fundamental to create two censuses (for languages and for inscriptions, respectively) whose goal is not a critical edition of inscriptions, but only their quantification and identification.

This process has led to the recognition of approximately twenty languages and circa 20,000 inscriptions. Among the problems of linguistic identification, the most complex ones affect the Sabellic and Celtic branches (both problems will be faced in two conferences in 2018) and the indirect sources for the Balcanic languages, where only Thracian has been clearly identified. The best defined languages are Iberian, Celtiberian, Lusitanian, the "Southwestern (or Tartessian) language" in Hispania (plus Vasconic and Aquitanian, indirectly evidenced in both sides of the Pyrenees); Gaulish in France; and Lepontic in Northern Italy. In Italy and its islands: Elymian, Sican and Sikel are recognised in Sicily; Venetic, Messapic, Ligurian, Faliscan,

4 [http://aelaw.unizar.es/database/languages]. 
Sabellian languages, Camunic, Raetic and Etruscan in the peninsula, being this last language the best represented of all, with more than 11,000 inscriptions.

\subsubsection{Challenges Arising from the Digitalization of Palaeo-European Epigraphy and Solutions Addressed in AELAW}

The particular nature of the AELAW database, developed as a census, has posed the following issues:

- The priority given to quantification, rather than to the content of inscriptions, has allowed resolution of a problem that was potentially unachievable in the census of inscriptions: the encoding of texts written in more than twenty writing systems. The language database does not pose any encoding problem.

- The creation of identifiers is particularly relevant in this stage. They will permit identification of the inscriptions whose fragments have been published in different moments, or the duplicated inscriptions (those whose fragments have been published as different inscriptions), the fake inscriptions, the inscriptions that are actually written in Latin, Greek or Phoenician. The collaboration with Trismegistos ${ }^{5}$, with which contact has already been established, will be fundamental in order to accomplish this task. The choice of the structure of the ID is at this moment a work-in-progress. Provisionally, the ID consists of the initial letter of the language of the text (e.g. Oscan=O, Venetic=V), allowing the user to clearly identify the epigraphic culture to which the text belongs, and a correlative number; but the team is currently assessing the possibility of assigning just a number as an ID of each inscription, just as Trismegistos does.

- The lexicographic solution of AELAW is relatively simple, compared to BDHesp. A working group specifically devoted to that task decided that the units of the languages database were languages, and the units of the inscriptions database were inscriptions, given that AELAW is mainly interested in the quantification of the data. Just as in BDHesp, both databases are linked to a third database containing the bibliographic references mentioned in the files.

We are firmly convinced that every progress made in the field of epigraphy, and PalaeoEuropean languages in particular, will be narrowly related to digital epigraphy, whose resources and potential must be fully exploited. This is what we believe after our experience with BDHesp.

5 [www.trismegistos.org]. See Chapter 15 in this volume. 


\section{Bibliography}

Beltrán, F. \& Jordán, C. (2017a). Celtibérico. Lengua, escritura, epigrafía (AELAW Booklet 1). Zaragoza: Prensas de la Universidad de Zaragoza.

Beltrán, F. \& Jordán, C. (2017b). Celtiberian. Language, writing, epigraphy (AELAW Booklet 1). Zaragoza: Prensas de la Universidad de Zaragoza.

Estarán, M.J. \& Beltrán, F. (2015). Banco de Datos Hesperia de Lenguas Paleohispánicas (BDHESP). II. Numismática paleohispánica. Vitoria: Libros UPV/EHU. Retrieved from [https://web-argitalpena. adm.ehu.es/pdf/UHPDF151886.pdf], 2017/12/12.

Gorrochategui, J. \& Vallejo, J.M. (forthcoming). The Parts of Hispania without epigraphy. In A.G. Sinner \& J. Velaza (Eds.), Palaeohispanic Languages and Epigraphies. Oxford: OUP.

Luján, E.R. (2005). Hesperia. The electronic corpus of Palaeohispanic inscriptions and linguistic records. Review of the National Center for Digitization, 6, 78-89.

Orduña, E. \& Luján, E.R. (2014). Implementing a database for the analysis of ancient inscriptions: the Hesperia electronic corpus of Palaeohispanic inscriptions. In T. Andrews \& C. Macé (Eds.), Methods and means for digital analysis of ancient and medieval texts and manuscripts (Lectio. Studies in the transmission of texts and ideas 1). Louvain: Brepols.

Orduña, E. \& Luján, E.R. (forthcoming). Philology and technology in the Hesperia databank. Journal of History, Literature, Science and Technology. Retrieved from [http://hesperia.ucm.es/LujanOrdunaAHList.pdf], 2017/12/12.

Orduña, E., Luján, E.R., \& Estarán, M.J. (2009). El banco de datos Hesperia. In F. Beltrán, J. d’Encarnação, A. Guerra, C. Jordán, \& B. Díaz (Eds.), Acta Palaeohispanica X. Actas del X Coloquio sobre Lenguas y Culturas Paleohispánicas (Palaeohispanica 9) (pp. 83-92). Zaragoza: Institución Fernando el Católico.

Salomon, C. (2017a). Raetic. Language, writing, epigraphy (AELAW Booklet 2). Zaragoza: Prensas de la Universidad de Zaragoza.

Salomon, C. (2017b). Rético. Lengua, escritura, epigrafia (AELAW Booklet 2). Zaragoza: Prensas de la Universidad de Zaragoza.

Untermann, J. (1975-1997), Monumenta Linguarum Hispanicarum (Vols. 1-4). Wiesbaden: Reichert Verlag.

Vallejo, J.M. (2016). Banco de Datos Hesperia de Lenguas Paleohispánicas (BDHESP). III. Onomástica paleohispánica. I. Antroponimia y teonimia. 1. Testimonios epigráficos latinos, celtibéricos y lusitanos, y referencias literarias. Vitoria: Libros UPV/EHU. Retrieved from [https://web-argitalpena. adm.ehu.es/listaproductos.asp?IdProducts=UHPDF163064\&titulo=Banco\%20de\%20Datos $\% 20$ Hesperia\%20de\%20Lenguas\%20Paleohisp\%E1nicas\%20(BDHESP).\%20III.\%200nom\%E1stica\%20 paleohisp\%E1nica.\%201.\%20Antroponimia\%20y\%20teonimia.\%201.\%20Testimonios\%20 epigr\%E1ficos\%20latinos,\%20celtib\%E9ricos\%20y\%20lusitanos,\%20y\%20referencias\%20literarias], 2017/12/12.

Velaza, J. \& Moncunill, N. (2017a), Iberian. Language, writing, epigraphy (AELAW Booklet 3). Zaragoza: Prensas de la Universidad de Zaragoza.

Velaza, J. \& Moncunill, N. (2017b), Ibérico. Lengua, escritura, epigrafia (AELAW Booklet 3). Zaragoza: Prensas de la Universidad de Zaragoza.

Wodtko, D. (2000), Monumenta Linguarum Hispanicarum (Vol. V.1). Wiesbaden: Reichert Verlag.

Wodtko, D. (2017a). Lusitanian. Language, writing, epigraphy (AELAW Booklet 4). Zaragoza: Prensas de la Universidad de Zaragoza.

Wodtko, D. (2017b). Lusitano. Lengua, escritura, epigrafía (AELAW Booklet 4). Zaragoza: Prensas de la Universidad de Zaragoza. 